\title{
DETERMINANTS OF FOREIGN DIRECT INVESTMENT IN NIGERIA: A MARKOV REGIME-SWITCHING APPROACH
}

\author{
Akinlo A. Enisan \\ Akinlo A. Enisan \\ Department of Economics, Obafemi Awolowo University, \\ Ile-Ife, Nigeria, \\ aakinlo@oauife.edu.ng \\ Article info \\ Paper category: Original Scientific Paper \\ Received: 21.3.2017. \\ Accepted: 27.4.2017. \\ JEL classification: E22, $\mathrm{CO}_{2}$
}




\begin{abstract}
Several studies have analyzed the movement of foreign direct investment in Nigeria using linear approach. In contrast with all existing studies in Nigeria, this paper runs several non linear FDI equations where the main determinants of FDI are determined using Markov-Regime Switching Model (MSMs). The approach enables us to observe structural changes, where exist, in FDI equations through time. Asides, where FDI regression equation is truly nonlinear, MSMs fit data better than the linear models. The paper adopts maximum likelihood methodology of Markov-Regime Model (MSM) to identify possible structural changes in level and/or trends and possible changes in parameters of independent variables through the transition probabilities. The results show that FDI process in Nigeria is governed by two different regimes and a shift from one regime to another regime depends on transition probabilities. The results show that the main determinants of FDI are GDP growth, macro instability, financial development, exchange rate, inflation and discount rate. This implies liberalization that stems inflation and enhance the value of domestic currency will attract more FDI into the country.
\end{abstract}

\title{
Keywords:
}

FDI; Markov-Regime Switching Model; Nigeria 


\section{INTRODUCTION}

Over the years, several studies have examined various related issues on foreign direct investment (FDI) in both developed and developing countries. The steady stream of theoretical and empirical research on FDI has to do with the impulses and responses it generates in an economy. FDI enhances growth through technology diffusion, human capital development, export promotion, employment generation and productivity growth (Li and Liu, 2005; Liu et al. 2009, Alfaro et al. 2010, Lee et al. 2012, de Mello Jr. 1999, Yao 2006, Ramirez, 2006). In view of the benefits of FDI, the dominant theme of research has been on factors influencing FDI. Early studies have focused on firms and industry specific variables in trying to explain FDI movement. However, in recent time, attention has shifted to spatial aspect of FDI and the subsequent consequences on the expansion of multinational enterprises into foreign markets. The shift of attention to the locational aspect of FDI can be attributed to the realization that countries compete with each other to attract a major share of FDI inflows thereby making changes in domestic policies key factors in attracting FDI. No doubt, location variables are major factors influencing FDI; however, their influence has continued to wane.

This explains the recent emphasis on the role of macroeconomic policies in the host country on FDI inflows (Dunning 2009; Vasconcellos and Kish 1998). It is not surprising therefore that several macroeconomic policy changes were made in most developing countries in the 1980s. These macroeconomic policy reforms were implemented in most developing countries not only to enhance domestic investment but also to foster increased foreign direct investment. Nigeria, in particular, introduced a comprehensive adjustment reforms in mid 1980 to promote increased foreign direct investment and economic growth. Moreover since early 1990s, many macroeconomic policies targeted at fostering increased foreign direct investment into the economy have been implemented. However in spite of all these measures, the share of aggregate FDI inflows in Nigeria relative to the GDP is still low when compared to some other African counties. Also, in aggregate terms, the amount FDI inflows to Nigeria compared to those of the Asian countries is relatively low ${ }^{1}$. Given the various macroeconomic reforms implemented in Nigeria and the aggregate FDI trends over time, it is quite instructive to understand the role of macroeconomic factors on FDI inflows into the country. Surprisingly, only few studies have focused on the effects of macroeconomic factors on inward FDI in Nigeria. Most existing works have focused on the effects of inward FDI on economic growth (Oyinlola 1995, Ekpo 1997, Akinlo 2004, Ekperware 2011, Omonkhanlem 2011 and Oyatoye et al. 2011). The few existing research works that examine the impact of macroeconomic vari-

1 As an illustration in 2002, the aggregate FDI inflows to Malaysia, Indonesia, India and Thailand were \$23,823.om, \$11,641.om, \$20,326.om and \$3०8, 180.om respectively. However, Nigeria received only $\$ 1005.0 \mathrm{~m}$. The pattern has not change significantly over the years. 
ables on inward FDI in Nigeria are faced with some limitations. First, they all failed to consider potential shifts in constant, trend and parameters of FDI function as they applied either co-integration or error correction modeling approach or vector error correction methodology. Second, all the known studies in Nigeria on the determinants of FDI only modeled a linear function without any formal test of its appropriateness. Therefore, this paper fills these gaps.

The remainder of the paper is organized as follows. In section 2, some stylized facts on FDI inflows into Nigeria are provided. Section 3 gives a capsule summary of literature review. Section 4 describes the methodology and the data. Section 5 presents the results and section 6 contains the conclusion.

\section{FOREIGN DIRECT INVESTMENT TO NIGERIA: SOME STYLIZED FACTS}

This section provides some stylized facts about FDI that motivates my analysis. The supporting data are presented in Tables 1 and 2.

Over the years, Nigerian Government has adopted several policies to attract FDI. In particular, government implemented the structural adjustment programme in mid 1986s. The programme entailed liberalization of the various sectors of the economy, attraction of foreign investors to the manufacturing sector through tax incentives, privatization of several government owned enterprises, and liberalization of the interest and exchange rate. These programmes were implemented in order to provide enabling environment for increased FDI inflows into the economy.

Aggregate FDI inflows into the country increased from $1003.2 \mathrm{~m}$ in 1970 to N9313.6m in 1986. Following the structural adjustment reforms introduced in mid 1986, aggregate FDI inflows increased to N10,4,36.1m and N119,391.6m in 1990 and 1995 respectively. However, as a result of the nullification of general election in 1993 and the attendant crisis, FDI inflows into the economy experienced downward trend from the year 1996 to 1999. However, the institution of democratic governance in late 1999 coupled with the introduction of various financial and economic reforms

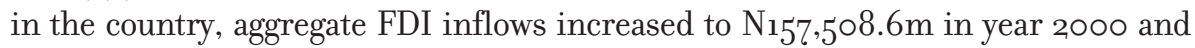
further up to $\mathrm{N} 324,129.3 \mathrm{~m}$ in 2005 and $\mathrm{N} 482,44,8.5 \mathrm{~m}$ in 2006. The aggregate FDI inflows into the country maintained upward trend to attain the peak of $\mathrm{N}_{4} 63,329.3 \mathrm{~m}$ in 2011. However, aggregate FDI inflows dropped slightly to $\mathrm{N}_{459,397.1 m}$ in 2012. Although, aggregate FDI inflows into the economy increased for most years between 1970 and 2012, it is important to note, that, the country has not fared well in attracting FDI when compared to other Asian countries as China, Malaysia, Indonesia, Thailand and India. 
Table 1.: FDI inflows in Nigeria: Some selected Years

\begin{tabular}{|c|c|}
\hline Year & FDI (Nm) \\
\hline $197^{\circ}$ & 1003.2 \\
\hline 1975 & 2287.5 \\
\hline 1980 & 3620.1 \\
\hline 1985 & 6804.0 \\
\hline 1990 & $104,36.1$ \\
\hline 1995 & 119391.6 \\
\hline 2000 & $1575 \circ 8.6$ \\
\hline 2005 & 324129.3 \\
\hline 2006 & $48244^{8} \cdot 5$ \\
\hline 2007 & $55^{24} 49^{8.6}$ \\
\hline 2008 & $399^{8} 41.13$ \\
\hline 2009 & 441271.1 \\
\hline 2010 & 44.0136 .1 \\
\hline 2011 & 463239.3 \\
\hline 2012 & $459^{397.1}$ \\
\hline
\end{tabular}

Source: CBN Statistical bulletin (various years)

In terms of sectoral distribution of FDI in Nigeria, some diversification particularly into the manufacturing sector has occurred over the years. As shown in table 2, unlike the traditional notion that FDI has concentrated more on the primary sector and particularly the extractive sub sector, the trend analysis of capital inflows into the country reveals that other sub sectors like manufacturing and service have benefitted from FDI inflows. Table 2 clearly shows that the mining and quarrying received the highest share of inward FDI in the zos but the percentage share for the subsector declined in the 80 s and early 9os. It however increased phenomenally in the late 1990 s and early 2000 s only to stabilize at 22 per cent from 2005 through 2012. The share of manufacturing FDI increased from average of 25.1 per cent between 1970-74 to average of 43.7 per cent between 1990 and 1994. The average share FDI to the manufacturing sub sector remained over 4, o per cent between 2005-2009 and 2010-2012. The share of trading and business sub sector which was high in the early zos declined to about 8.2 percentage average between 2005 and 2012 . 
Table 2.: Sectoral Composition of FDI in Nigeria: 1970-2012 Percentage

\begin{tabular}{|c|r|r|r|r|r|r|r|}
\hline Year & $\begin{array}{c}\text { Mining \& } \\
\text { Quarrying }\end{array}$ & $\begin{array}{c}\text { Manufac- } \\
\text { turing }\end{array}$ & Agriculture & $\begin{array}{c}\text { Transport } \\
\text { \& Commu- } \\
\text { nication }\end{array}$ & $\begin{array}{c}\text { Building \& } \\
\text { Construc- } \\
\text { tion }\end{array}$ & $\begin{array}{c}\text { Trading \& } \\
\text { Business }\end{array}$ & $\begin{array}{c}\text { Miscella- } \\
\text { neous }\end{array}$ \\
\hline $1970-1974$ & 51.2 & 25.1 & 0.9 & 1.0 & 2.2 & 16.9 & 2.7 \\
$1975^{-1979}$ & 30.8 & 32.4 & 2.5 & 1.4 & 6.4 & 20.4 & 6.1 \\
$1980-1984$ & 14.1 & 38.3 & 2.6 & 1.4 & 7.9 & 29.2 & 6.5 \\
$1985^{-1989}$ & 19.3 & 35.3 & 1.4 & 1.1 & 5.1 & 32.6 & 5.2 \\
$1990-1994$ & 22.9 & 43.7 & 2.3 & 1.7 & 5.7 & 8.3 & 15.4 \\
$1995^{-1999}$ & 43.5 & 23.7 & 0.9 & 0.4 & 1.8 & 4.5 & 25.3 \\
$2000-2004$ & 33.7 & 28.8 & 0.7 & 1.2 & 2.4 & 7.7 & 25.6 \\
$2005^{-2009}$ & 22.5 & 4.9 .7 & 0.4 & 2.1 & 2.2 & 8.2 & 23.9 \\
$2010^{-2012}$ & 22.3 & 4.0 .4 & 0.4 & 2.1 & 2.2 & 8.2 & 24.3 \\
$1970-2012$ & 27.3 & 36.0 & 0.6 & 1.7 & 2.3 & 7.9 & 24.3 \\
\hline
\end{tabular}

Source: CBN Statistical Bulletin (various years)

In general, the share of FDI inflows into the country is still low. The country needs more FDI inflows given her low income and low domestic savings. External capital is needed for investment and development. This explains why identifying various factors that drive FDI inflows into the country becomes imperative.

\section{LITERATURE REVIEW}

Several theories have been propounded to provide logical foundation on the determinants of FDI in the 1930s. These include the internationalization, monopolistic competition and market structure theories. However, realizing the inadequacies of each of the existing traditional theories in explaining FDI, Dunning (1977, 1981, 1993 and 1988) provided the eclectic paradigm. The eclectic paradigm synthesizes already existing theories on MNEs into what is popularly referred to OLI framework. The OLI framework argues that what determine a country decision to invest abroad are three sets of advantages namely; Ownership (O), Location (L), and Internationalization. The ownership advantages encompasses all the technological, managerial, and marketing assets that allow a firm to compete with others in the markets it serves irrespective of the disadvantages of being foreign. The locational advantages consist of tangible and intangible resources that make the chosen country attractive business environment. Internalization advantages are attributed to own production as against producing through a partnership arrangement such as licensing or a joint venture. They arise from exploiting imperfections in external markets. This includes reduction of uncertainty and transaction costs for more efficient knowledge generation and reduction of state generated imperfections including tariffs, control of foreign exchange and subsidies. 
It is argued that the three advantages (ownership, locational and internalization) work together to influence the flow of FDI (Dunning, 2009). However, considering the fact that most firms that intend to invest abroad often possess ownership and internalization advantages; location factor therefore remains the critical consideration. This explains why emphasis, particularly in developing countries, is placed on country specific factors that tend to reduce business risk and enhance market potentials. As pointed by Kiymaz (2009) and Boateng et al. (2014), macroeconomic factors including GDP, exchange rate and inflation among several others, provide the means for assessing market potentials and market risk. Indeed, it is contended that internal influences are intricately linked to a firm's assets, competencies and competitive advantages (Hawawini and Schill, 1994). All the same, the role of external or environmental factors in determining decision to investment cannot be completely waved off. As such, FDI would move to a country where it could benefit from a new market that provides a favourable economic environment, reduces cost and risk and enhances firms' competitive advantage (Boateng et al. 2015).

Empirically, several studies in both developed and developing economies indicate that FDI depend largely on economic fundamentals such as the degree of macroeconomic and political stability and growth prospects. Most existing studies equally identify good infrastructure, skilled labour force, natural resources endowment, market size, financial development as major determinants of FDI. Few recent studies on the determinants of FDI include Ramirez (2006), Ang (2008), Jeon and Rhee (2008), Buckley et al (2007), Oladipo (2008), Mohamed and Sidiropolous (2010), Feils and Rahman (2008), Bukley et al. (2015) . However, empirical findings from existing studies are inconclusive. While some studies found positive relationship between FDI and some of its determinants; others reported negative. Moreover, most of the existing studies have adopted linear methods of analyzing the linkage between FDI and its determinants ${ }^{2}$.

With specific reference to Nigeria, few studies have examined FDI and its determinants. These studies include Obadan (1982), Aremu (1997), Anyanwu (1998), Ajakaiye (1995, 1997), Chette (1998), Wafure and Nurudeen (2010), Thaddeus and Yadirichukwu (2013), Abubakar and Abdullahi (2013) and Akenbor and Tennyson (2014). Several of the studies identify market size, exchange rate and natural resources availability as major determinants of FDI in Nigeria (Obadan 1982, Wafure and Nurudeen 2010, Abubakar and Abdullahi 2013 and Akenbor and Tennyson 2014). Some other factors identified in Nigeria as determinants of FDI are trade policies (Obadan 1982 and Anyanwu1998), interest rate, domestic credit and legal system (Akenbor and Tennyson, 2014) and stock market development (Wafure and Nurudeen, 2010). Few other factors identified by some Nigerian empirical evidences

2 As argued in the literature, the ambiguity of the findings of these studies may be due to the use of different models, and the models may de sensitive to the samples selected and nonlinearity may be important. If the nonlinearities are not statistically controlled for, any relationship between FDI and its determinants might be questionable as the correlation between them might be wrongly specified, and thence erroneous inferences might be drawn. 
with negative effects on FDI are corruption, political risk and trade openness (Akenbor and Tennyson 2014). Thaddeus and Yadirichukwu (2013) show that interest rate, exchange rate and inflation rate have negative effect on FDI while Wafure and Nurudeen (2010) show that openness, inflation and infrastructural development do not have significant effect on FDI inflows in Nigeria.

There are few observations from the studies on FDI determinants in Nigeria. First, controversies still surround the impact of many of the variables on FDI. For example, while some found positive relationship between exchange rate and FDI, few others obtained negative effect. The same applies to such factors as openness, interest rate, infrastructure amongst others. Second, none of the studies has looked at the role of oil reserves on FDI inflows. Finally, all the existing studies on FDI determinants follow constant parameter (linear) time series. None of them consider regime changes or regime shift. There is the need to fill these gaps in the literature. Hence, the main goal of the paper is to determine the statistically significant parameters on FDI in Nigeria taking cognizance of structural changes in parameters by employing Markov-Regime Switching Model (MSM).

\section{METHODOLOGY}

The study utilizes state space model (SSM) based on two main reasons. One, it allows unobserved variables within an observed model. Two in estimation procedure, SSM uses robust algorithm to reach strong optimization (convergence) through iterations in a dynamic system. As pointed out by Kim and Nelson (2000), in a SSM with Markov-Switching, the state variable is an unknown parameter evolving through stochastic difference equation. Following the seminal paper of Hamilton (1988) on regime switching, the shifts in regime or cycles in variables are estimated by MSM. Indeed, several advantages that are associated with SSMs have been noted in the literature. For one, MSM is capable of taking care of asymmetry and persistence in extreme observations in data. For another, it can attain solution in a nonlinear context (Anas et al. 2004) $)^{3}$. In short, Markov Switching-Regime model has become an alternative to linear models such as autoregressive (AR), moving average (MA) or (autoregressive integrated moving average (ARIMA) model, as it allows change in parameters in a stochastic process ${ }^{4}$. MSM are capable of handling non-

3 Several studies have used this methodology particularly in the developed economies. These include Hamilton (1989), Durland and McGurdy (1994), Ghysels (1994), Chauvet (1998), Smith and Summers (2005) and Lam (2004)

4 As noted by Kuan (2002, 2010), although linear models such as linear bivariate or multivariate classical regression models, autoregressive (AR), moving average (MA) or autoregressive integrated moving average (ARIMA) can apture the dynamics in data, they are unable to handle some nonlinear properties such as asymmetry, dependency weights and volatility. Generally, it is well established in the literature that Markov approach presents more sophisticated methods and original results compared to other structural breaks tests such as Chow test (Hamilton, 1989, 1990). 
linear properties such asymmetry, dependency, weight and volatility. Specifically in relation to our study, this approach is appealing because it fits with the fact that FDI can perform differently in different sub-periods. Asides, MSM permits two or more process to exist with a series of shifts between the states occurring in a probabilistic manner, so that shifts occur exogenously rather been imposed. Another motivation to use the approach is the patterns of FDI into Nigeria, which historically have switched in response to many political and macroeconomic shocks. Finally, with the smoothed probabilities graph, MSM allows us to have a probabilistic approach of appurtenance of each regime, while explaining FDI by its determinants, conditionally with all information of the sample. Through stochastic process, switches in volatility from low level (contraction) to high level (expansion) are captured in a probabilistic procedure as shown by MSM equation $\mathbf{1}^{5}$.

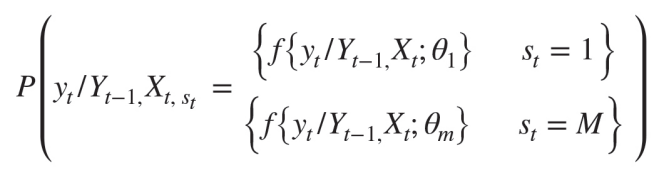

where $Y_{t-i}\left\{y_{t-j}\right\}_{i}^{\infty}=0$ shows the history of $y_{t}$ which depends on unobservable state variables $s_{t} \in\{1,2, \ldots \ldots, M\}$, which represents the probability of being in a particular state of the data. $X_{t}$ and $\theta_{m}$ with $\mathrm{m}=1,2,3, \ldots, \mathrm{M}$ are exogenous variables and parameter vector, respectively (Bilgili et al. 2012 and Krolzig 2000)

For a two state Markov chain, the four transition probabilities are given as:

$$
\begin{aligned}
& P\left\{s_{t}=1 / s_{t-1}=1\right\}=\rho_{11} \\
& P\left\{s_{t}=0 / s_{t-1}=1\right\}=1-\rho_{11} \\
& P\left\{s_{t}=0 / s_{t-1}=0\right\}=\rho_{00} \\
& P\left\{s_{t}=1 / s_{t-1}=0\right\}=1-\rho_{00}
\end{aligned}
$$

where $s_{\mathrm{t}}=0$ or 1 represents the unobserved state of equation (Hamilton, 1989). The transition probability takes the range of $o<\rho_{i j}<1$ and the transition probabilities summed up to one.

As well, the transition probabilities measure persistence in the regime. Then, the expected duration of a typical recession is written as a reverse function of the probability to remain in recession.

$$
\sum_{k=0}^{\infty} K_{\rho 00}^{k-1}\left(1-\rho_{00}\right)^{-1}
$$

and the expected duration of a typical expression is given as:

5 In general, the low level is otherwise referred to contraction phase or Regime o while the high level is otherwise called the expansion phase or Regime 1. 


$$
\sum_{k=0}^{\infty} K_{\rho 11}^{k-1}\left(1-p_{11}\right)=\left(1-\rho_{11}\right)^{-1}
$$

Assuming $\Delta y_{t}$ denotes growth rate of $y_{t}$ while $\mu_{t}$ represents the mean growth of $y_{t}$. The general form of Makov-Switching model takes the form:

$$
\Delta y_{t}-\mu\left(s_{t}\right)=A_{1}\left(\Delta y_{t-1}-\mu\left(s_{t-1}\right)\right)+\ldots \ldots+A_{p}\left(\Delta y_{t-\rho}-\mu\left(s_{t-\rho}\right)\right)+u_{t}
$$

where $u_{t}$ is normally and independently distributed.

The low (repression) phase $\left(s_{t}=0\right)$ and high (expansion) phase regimes are related with different conditional distributions of $\Delta y_{t}$. $\mu$, however, depends on regimes (Bilgili et al 2012, Krolzig 2001). As severally noted in the literature, Markov Switching model given as equation 3 can be extended into a multivariate $\mathrm{MSM}^{6}$, which is adopted in this paper to analyze the behaviour of FDI in Nigeria. This is formally stated as

$$
F D I=\beta_{0}\left(s_{t}\right)+\beta_{1 t}\left(s_{t}\right)+\sum_{i=2}^{n} B_{i} X_{1 t}\left(s_{t}\right)+u_{t}
$$

where FDI is foreign direct investment, $s$ is the state (regime), $t$ is trend, $X_{\mathrm{i}}$ is the $\mathrm{ex}^{-}$ planatory variable $i$ and is the residual time and t is time subscript. The state term in the equation (6) is a vector of states; state (regime o) and state (regime 1 ) or equivalently corresponds to vector of regimes. Hence, the parameters of $B_{\circ}, B_{1}, \ldots, B_{n}$ denotes time varying parameters.

Maximum likelihood estimation of this model is performed with quarterly data 1986:1 - 20102:4. This is with a view to investigating the possible structural changes (regime shifts) in level, and/or trends as well as possible changes in parameters of vector $\mathbf{b}$ in FDI-MSM equations through the transition probabilities as explained in Hamilton $(1989,1990)$ by conducting analytical derivatives of Feasible Sequential Quadratic Programming explicitly detailed in the work of Lawrence and Tits (2001 $)^{7}$.

Data

The quarterly data used in the work were obtained from the Central Bank of Nigeria, Statistical Bulletin 2013 edition; IMF, International Financial Statistics and OPEC, OPEC Statistical Bulletin, 2006-2012 ${ }^{8}$. GDP is the real GDP. The real GDP

6 Examples of multivariate MSM can be found in the works of Simon (1996), Jeanne and Masson (2000), Raymond and Rich (1997), Frommel et al. (2005), Ribeiro and Pereira (2010), Liu and Mumtaz (2010).

7 The full description of the steps involved in the analytical derivatives of the Feasible Sequential Quadratic Programming can be found in the work of Lawrence and Tits (2001) titled "A computational efficient feasible quadratic programming algorithm, SIAM Journal on Optimisation, 11, 1092-118".

8 A natural starting point for any time series analysis is the stationary test of the data to be used. All the variables were tested for stationarity using Kwiatkowski-Phillips-Scmdmit-Shin (1992)-KPSS stationarity. All the variables were stationary at first difference. This actually explains the use of growth rates of the variables in our estimation. 
is defined as nominal GDP deflated by the consumer price index $(1990=100)$. Exchange rate is the real exchange rate defined as domestic currency per unit of U.S. dollar, discount rate is the Central Bank of Nigeria minimum rediscount rate and inflation rate is the consumer price index $(1990=100)$. Export is the total real export, import is total real import, financial development is measured as the ratio of private credit to GDP, and macro instability refers to macroeconomic uncertainty related to output fluctuations. It is constructed based on a GARCH $(1,1)$ specification in a simple equation in which the logarithmic real GDP follows an AR(1) process. There is no quarterly series on foreign direct investment and crude oil reserves. However, the annual series of these variables were decomposed into quarterly values using linear quadratic method from E-views package. In estimation, the levels of index (CPI), rediscount and exchange rates and the percentage growth rates of FDI, GDP, export, import, and financial development are used throughout MSM predictions. The growth rates were obtained using equation:

$$
\left.\mathrm{Z}_{\mathrm{t}}=100\left\{\left(\mathrm{Z}_{\mathrm{t}}-\mathrm{Z}_{\mathrm{t}-4}\right) / \mathrm{Z}_{\mathrm{t}-4}\right)\right\}
$$

where $\mathrm{Z}_{\mathrm{t}}$ and $\mathrm{Z}_{\mathrm{t}-4}$ denote time series observation at time $\mathrm{t}$ (current quarter) and at time $\mathrm{t}-4$ (four quarters earlier), respectively.

\section{ESTIMATION RESULTS}

The results of the four alternative Markov-Switching models 1-4 denoted MSM1, MSM2, MSM3 and MSM4, respectively are shown in table $3{ }^{9}$. Column 1 of table 1shows constant and potential explanatory variables of FDI to be analyzed in alternative MSMs. Columns 2, 3, 4 and 5 of table 3 show the estimation results of Markov Regime-Switching Model ${ }_{1}\left(\mathrm{MSM}_{1}\right)$, Markov Regime-Switching Model 2. (MSM2), Markov Regime-Switching Model 3 (MSM3) and Markov RegimeSwitching Model 4 ( $\mathrm{MSM}_{4}$ ) respectively. As shown in column 2 of table 3, MSM1 uses, in addition to constant and trend, the independent variables of GDP growth, macroeconomic uncertainty and financial development following nonlinear time series regression in which FDI growth serves as the dependent variable. The results show that constant, trend and macroeconomic uncertainty (at low regime, Regime o) are significant determinants of FDI in Nigeria. GDP growth rate is positively correlated with high FDI growth rate (Regime 1) but negatively correlated with low FDI growth (Regime o). However, the coefficient is not significant in both Regimes. As expected, Nigerian FDI growth rate is positively correlated with Nigerian financial development at both regimes though the coefficient is only significant at the high regime (Regime 1 ). This shows that as financial devel-

9 The study estimated four models because employing all the variables together in a model would generate problem of degree of freedom. Indeed, when the number of parameters to be estimated was increased in each MSM, the results showed either poorer goodness of fit measurements or no strong convergence. 
opment increases, the FDI growth rate also increases at Regime 1 and Regime $0^{10}$. This indicates that financial development possibly acts as a mechanism in facilitating the adoption of new technologies in the domestic economy. Hence, the provision of efficient credit and financial services by the financial system may greatly facilitate technological transfer and induce spillover efficiency. Macroeconomic instability tends to encourage FDI in Regime o as against conventional wisdom ${ }^{\mathbf{1 1}}$. This possibly suggests that foreign investors perceive a higher level of uncertainty as greater investment return ${ }^{12}$. As a matter fact, a substantial share of FDI to Nigeria is in the petroleum sub sector. Investment in the sector might be so profitable such that returns after adjusting for risk remains quite substantial. The major implication of this finding is FDI may not enhance growth as composition of FDI may have shifted towards more speculative type of investment.

Table 3.: Markov Regime Switching Models for FDI growth: 1986-2012

\begin{tabular}{|l|r|r|r|r|}
\hline \multicolumn{1}{|c|}{$\begin{array}{c}\text { Variables/ } \\
\text { Regimes }\end{array}$} & \multicolumn{1}{c|}{ MSM1 } & \multicolumn{1}{c|}{ MSM2 } & \multicolumn{1}{c|}{ MSM3 } & \multicolumn{1}{c|}{ MSM4 } \\
\hline Constant & 1384.3 .09 & 15499.05 & $13355.7^{3}$ & 424.75 \\
(Regime o) & $(0.000)$ & $(0.000)$ & $(0.000)$ & $(0.013)$ \\
Constant & 1635.18 & 12692.64 & 12633.65 & 15643.38 \\
(Regime 1) & $(0.000)$ & $(0.000)$ & $(0.000)$ & $(0.000)$ \\
GDP growth & -0.000031 & 0.004 .27 & -0.00038 & 0.00156 \\
Regime 0 & $(0.656)$ & $(0.107)$ & $(0.000)$ & $(0.000)$ \\
GDP growth & 0.0000169 & -0.00018 & 0.0012 & -0.00019 \\
Regime 1 & $(0.2024)$ & $(0.052)$ & $(0.438)$ & $(0.000)$ \\
Trend & 57.87 & $82.5^{3}$ & 344.47 & 250.754 \\
Regime o & $(0.000)$ & $(0.0005)$ & $(0.000)$ & $(0.069)$ \\
Trend & 236.26 & 319.92 & 78.93 & 133.38 \\
Regime 1 & $(0.000)$ & $(0.000)$ & $(0.438)$ & $(0.000)$ \\
Macro instability & 2597.24 & -32121.79 & 1850.08 & -18763.23 \\
Regime o & $(0.000)$ & $(0.137)$ & $(0.121)$ & $(0.000)$ \\
Macro instability & -35.31 & 1723.78 & 485.89 & 329.28 \\
Regime 1 & $(0.545)$ & $(0.005)$ & $(0.177)$ & $(0.239)$ \\
\hline
\end{tabular}

10 This finding is consistent with the findings of Deichmann, Karidis and Sayek (2003) and Ang (2008) but contradict the findings of Anyanwu and Erhijakpor (2004), Anyanwu (2011) and Walsh and Yu (2010).

11 Some of the existing studies that found insignificant correlation between instability (measured as political risk) include Edwards (1990), Jaspersen et al. (2000), Hausmann and Fernandez-Arias (2000) and Asiedu (2002).

12 Indeed, the study by Wafure and Nurudeen (2010) on Nigeria found that political instability had significant positive effect on FDI inflows. His results showed that a 1 per cent increase in political instability leads to 1.6 per cent increase in FDI inflows. According to them, the positive effect of political instability on FDI reflect e the situation in the in the Nigeria's oil sector that has continued to attract more foreign investment regardless of political situation in the country. 


\begin{tabular}{|c|c|c|c|c|}
\hline $\begin{array}{c}\text { Variables/ } \\
\text { Regimes }\end{array}$ & MSMı & $\mathrm{MSM}_{2}$ & MSM3 & $\mathrm{MSM}_{4}$ \\
\hline $\begin{array}{l}\text { Financial } \\
\text { development }\end{array}$ & $57^{3} 4.60$ & 52523.13 & $-8319 \cdot 7^{8}$ & \\
\hline Regime o & $(0.276)$ & $(0.005)$ & $(0.000)$ & \\
\hline $\begin{array}{l}\text { Financial } \\
\text { development }\end{array}$ & 917.38 & $-155 \circ 4.55$ & 62121.74 & \\
\hline Regime 1 & $\left(0.05^{8}\right)$ & $(0.000)$ & $(0.000)$ & \\
\hline Oil reserves & & $0.5^{880}$ & & \\
\hline Regime o & & $(0.174)$ & & \\
\hline Oil reserves & & 0.2716 & & \\
\hline Regime 1 & & $\left(0.5^{13}\right)$ & & \\
\hline Import growth & & & -0.0063 & \\
\hline Regime o & & & $(0.879)$ & \\
\hline Import growth & & & $-0.054^{3}$ & \\
\hline Regime 1 & & & $(0.799)$ & \\
\hline Export growth & & & 0.0079 & \\
\hline Regime o & & & $(0.831)$ & \\
\hline Export growth & & & -0.652 & \\
\hline Regime 1 & & & (0.019) & \\
\hline Exchange rate & & & & 66.474 \\
\hline Regime o & & & & $(0.0016)$ \\
\hline Exchange rate & & & & 113.604 \\
\hline Regime 1 & & & & $(0.000)$ \\
\hline Inflation rate & & & & -132.37 \\
\hline Regime o & & & & $(0.042)$ \\
\hline Inflation rate & & & & -19.073 \\
\hline Regime 1 & & & & $(0.000)$ \\
\hline Discount rate & & & 136.09 & -165.47 \\
\hline Regime o & & & $(0.0006)$ & $(0.123)$ \\
\hline Discount rate & & & 115.91 & $4^{3.87}$ \\
\hline Regime 1 & & & $(0.0001)$ & $(0.094)$ \\
\hline
\end{tabular}

Source: Autor`s

Compared to MSM1, MSM2 incorporates oil reserves as an additional explanatory variable. The incorporation of oil reserves is based on the argument that availability of natural resources is a major determinant of FDI to host country. It is contended that FDI takes place when a country richly endowed with natural resources lacks the amount of capital or technical skill needed to extract or/and sale to the world. Hence, vertical FDI occurs in the host country by foreign firms in order to produce raw materials and inputs for production. Constant, trend, macroeconomic instability (Regime 1) and financial development all have significant coefficients as obtained in MSMı. Oil reserves has positive impact on FDI inflows into the country 
as expected, but the coefficient is not significant. This result shows that availability of oil reserves is not a major determinant of FDI inflows into the country. What this possibly suggests is that the huge FDI inflows into the oil sector might be explained by the high level of return on investment in the sector arising from lax policy on capital and remittances and massive corruption in the sub sector ${ }^{13}$. Indeed, few studies including Al-Sadig (2009) and Kim, (2010) have reported positive effect of corruption on FDI inflows.

The third nonlinear evaluation of FDI with its determinants is given as MSM3. It employs besides, constant and trend, the independent variables, GDP growth rate, macro instability, financial development, import growth, export growth and discount rate. Constant term has significant positive sign at Regime $\mathrm{o}$ and Regime 1 at $1 \%$ level of significance. GDP is only positive and significant in Regime 0 . Trend is positive in both regimes but significant only in Regime o. Financial development is significant in both regimes but the coefficient is negative in Regime o but positive in Regime 1. Import growth has negative non significant effect in both regimes. This shows that Nigeria's import growth dampens FDI inflows into the country. Similar results have been obtained by Bilgili et al. (2012) for Turkey. The negative effect of export growth on FDI emerges in high FDI growth rate periods while non significant positive effect of export growth on FDI appears on low FDI growth rate periods. This means that when Nigeria's capability to export increases, FDI shrinks. Discount rate has positive effect on FDI in both Regimes and the coefficient significant at $1 \%$ significance level. This simply shows that as the discount rate increases, FDI grows. This should not come as a surprise because for most periods before mid 1986, the interest rate was administratively fixed by the Monetary Authority which led to high financial repression and inefficiency with adverse impact on investment and economic growth. Hence, the liberalization of the interest rate in early 1987 might have led to increased efficiency in resource allocation and thus increased domestic and foreign investment. This finding supports the argument of Yang et al. (2000) and Jeon and Rhee (2008) that higher interest rates in the host country make foreign investment more attractive as they lead to profitable investment. Our finding is consistent with the Boateng et al. $(2015)$ result for Norway.

The final alternate nonlinear evaluation of FDI with its determinant is reported as $\mathrm{MSM}_{4}$ in table 3. $\mathrm{MSM}_{4}$ employs, besides, constant and trend, the independent variables GDP growth rate, macroeconomic uncertainty, exchange rate, inflation and discount rate. As in MSM1 and MSM2, constant and trend are both positive and significant at both $1 \%$ and $10 \%$ significance levels. GDP growth rate is positively related to FDI in Regime o but negative in Regime 1. When GDP growth rate increases, FDI grows and vice versa. $\mathrm{MSM}_{4}$, reveals that FDI growth is associated positively with ex-

13 Indeed, over the years, the oil sector has been characterized by massive level of corruption running into several billions of Dollars. The operation of the subsector has shrouded in secrecy without transparency and accountability. In 2012, the then Governor of Central Bank of Nigeria alleged that \$20 billion was stolen from the oil revenue that accrued to Federal Government of Nigeria. 
change rate at both regimes (Regime o and Regime 1). This suggests that an appreciation of the domestic currency (Naira) encourages FDI inflows into economy. This result seems to contradict the findings of some existing studies that depreciation of exchange rate leads to increase in FDI inflows (Froot and Stein 1991, Ang 2008, Azrak and Wynne 1995 and Ramirez 2006). The finding that appreciation leads to increase FDI inflows could possibly be explained by the fact that the nominal return that asset yields in foreign currency should be the main consideration as against the price of the asset in factor explaining FDI inflows. This is as discussed by McCulloch (1989). Our result actually supports the argument by Campa (1993) that positive relationship exists between exchange rate and FDI. Campa argues that an appreciation of the host country's currency will spur increase investment expectation of increased future profit. Empirical study by Boateng, et al. (2015) for Norway supports the postulation by Campa (1993). Inflation is negatively correlated with FDI growth and is significant at $5 \%$ and $1 \%$ significance levels for Regime $\circ$ and Regime 1 respectively. This result shows that high inflation rates in the host country dampens FDI inflows. This finding can be explained by the fact that high inflation rate reduces the real value of earnings in local currency for inward investment firms as explained by Buckley et al. (2007). Our finding is consistent with general finding in the literature including Nnadozie and Osili (2004), Khair-Uz-Zaman and Awan (2006), Anyanwu, (2011), Wafure and Nurudeen (2010) and Boateng et al. (2015).

As shown in table 4, all the models seem to perform well. However, MSM1 model seems to fit the data best according to lowest AIC of 13.66908 and highest Log Likelihood of -709.4,616 among others. The second best model in the work in terms of AIC and Log-likelihood is MSM3. Using the variance as a measure of goodness of fit, the variance of Regime 1 (102.80) and Regime o (5.09638e-0o6) choose MSM1 as best model among alternatives in this work.

Table 4.: Switching variances, transition probabilities and test statistics of Markov RegimeSwitching Models: 1986:1-2012:4

\begin{tabular}{|l|r|r|r|r|}
\hline & \multicolumn{1}{|c|}{ MSM1 } & \multicolumn{1}{c|}{ MSM2 } & \multicolumn{1}{c|}{ MSM3 } & \multicolumn{1}{c|}{ MSM4 } \\
\hline Sigma o & $5.09638 \mathrm{e}-006$ & $6.819972 \mathrm{e}-006$ & $6.529383 \mathrm{e}-006$ & $6.61635^{3} \mathrm{e}-006$ \\
Sigma 1 & 102.80 & 135.38 & $130.5^{8}$ & 132.32 \\
$\mathrm{P}[0 / 1]$ & 0.020910 & 0.027468 & 0.033239 & 0.036729 \\
$\mathrm{P}[1 / 1]$ & 0.979090 & $0.9725^{32}$ & 0.966764 & 0.963271 \\
$\mathrm{P}[1 / 0]$ & 1.000000 & 1.000000 & 1.000000 & 1.00000 \\
P[o/o] & 0.00000 & 0.000000 & 0.000000 & 0.000000 \\
Log likelihood & -709.4614 & -896.378 & $-863.35^{3} 4$ & $-887.165^{3}$ \\
AIC & 13.66908 & 17.02908 & 16.49259 & 16.91498 \\
LinearityTest $\left(\chi_{2}\right)$ & 2686.4873 & 2351.3589 & 2828.429 & 2383.764 \\
& $(0.0000)$ & $(0.0000)$ & $(0.0000)$ & 0.0000 \\
\hline
\end{tabular}

Note: Below the linearity test values are the $\mathrm{p}$-values Source: Autor`s 
In general, the four models perform well considering the fact that they all attain strong convergence through SQPF analytical derivatives. Asides, the differences amongst the models in terms of signs and significance of the coefficients are, to a reasonable extent not sharp. Constant has similar signs and significances. The same applies to Trend except for MSM3 (Regime 1) and MSM4 Regime (o) where the coefficients are not significant at $5 \%$ level. Financial development has similar signs and significance. However, minor differences exist. The coefficient of financial development is negative in both MSM2 (Regime o) and MSM3 (Regime 1). The other difference is that GDP growth rate is positive and significant at MSM4 (Regime o), it is negative and significant at $\mathrm{MSM}_{4}$ (Regime 1 ) and MSM3 (Regime o). The coefficients of GDP growth rates are not significant at both Regimes in MSM1 and MSM2.

As revealed in table 4, linearity test show that the null of linearity of four MSMs are rejected at $1 \%$. This simply means that for the four MSMs, conducting nonlinear estimations are more desirable than their linear counterparts. The transition probabilities for the four MSMs are also shown in table 4. They all show that when the current state of FDI in Regime 1 at time t, the probability of jumping FDI from Regime 1 to Regime $\circ$ at time $t+1$ is $0.0295^{86}$ on average. The probability is lowest in MSM1. As the current state is Regime 1 at time t, the probability of remaining at Regime 1 at time $t+1$ is 0.97041425 on average. From table 4, probability of FDI growth's switching from current Regime o to Regime 1 is 1.0000 . It can be asserted that the cumulative effect of any shock in the system (in MSM FDI equation) to Nigerian FDI growth rate is persistent in Regime 1 while in Regime o, the responses of FDI to shock(s) is temporary.

It is possible to observe the time duration (Regime Classification) of the smoothed probabilities. Figures $1 \mathrm{a}-\mathrm{b}$ to Figures $4 \mathrm{a}-\mathrm{b}$ provide the smoothed probabilities of Regime o and Regime 1 of MSMı to MSM4 respectively. Regime o time points as revealed in Figure 1a are 1991:1; 1998:1-1998:4 and 2001:1-2004:4. Figure 1b: shows that Regime 1 covers periods 1986:3-1990:4, 1992:2-1997:4, 1991:11999:4 and 2001:1-2012:3. 
Figure 1.: Probability of regime o smoothed from MSM1. b: Probability of regime 1 smoothed from MSM1

a

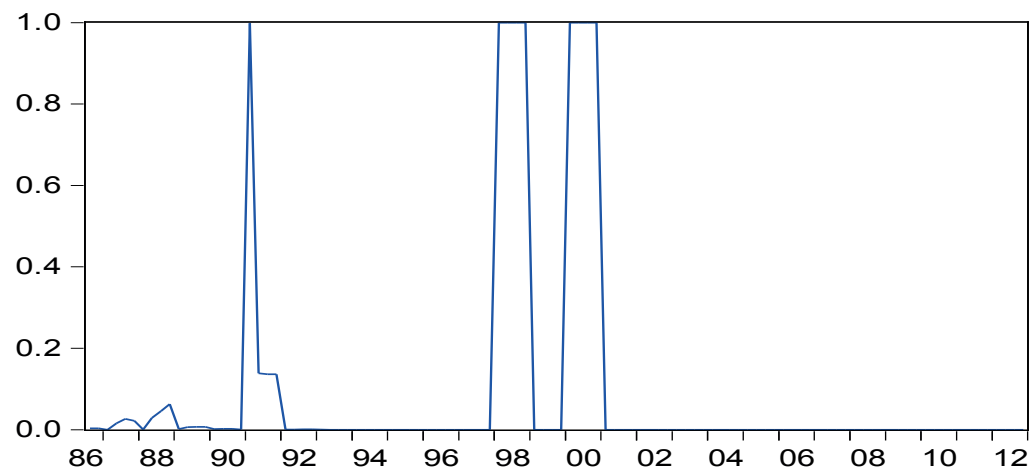

$\mathrm{b}$

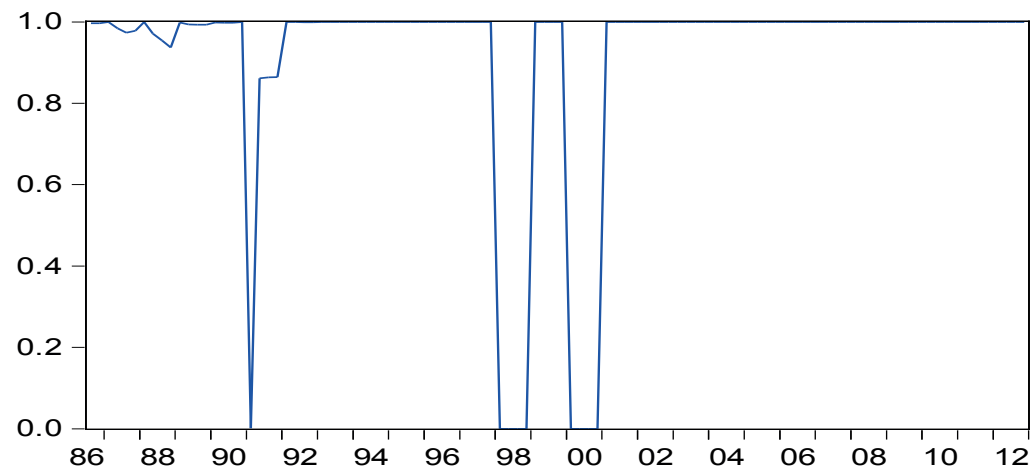

Source: Autor`s

With respect to MSM2, Regime o time points are 1987:1-1990:1 and 1994:42000:1. However, from Figure 2b, Regime 1 periods include 1991:3-1993:2 and 2000:3-2012:3. From Figure 3 (a) the time points are 1991:2-1992:2; 2000:1-2006:4 and 2009:1-2012:3. Figure 3b reveals that Regime 1 covers periods 1986:2-1990:3 and 1993:3-1999:4. 
Figure 2.: Probability of regime $\circ$ smoothed from MSM2. b. Probability of regime 1 smoothed from $\mathrm{MSM}_{2}$

a

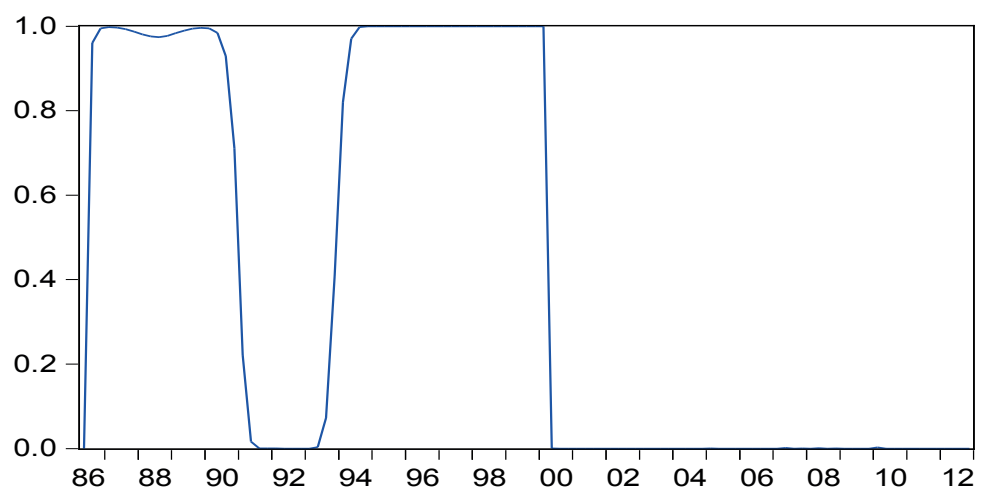

$\mathrm{b}$

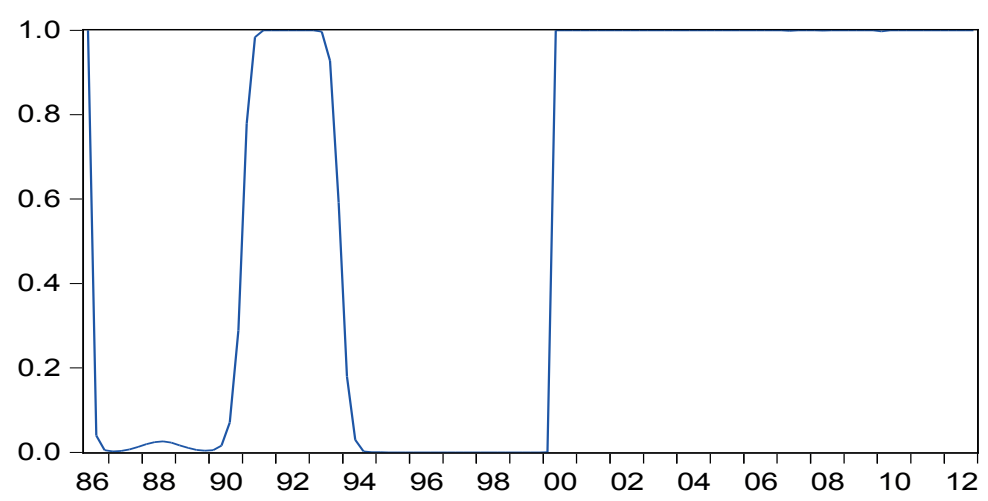

Source: Autor's 
Figure 3.: Probability of regime o smoothed from MSM3. b: Probability of regime 1 smoothed from MS a

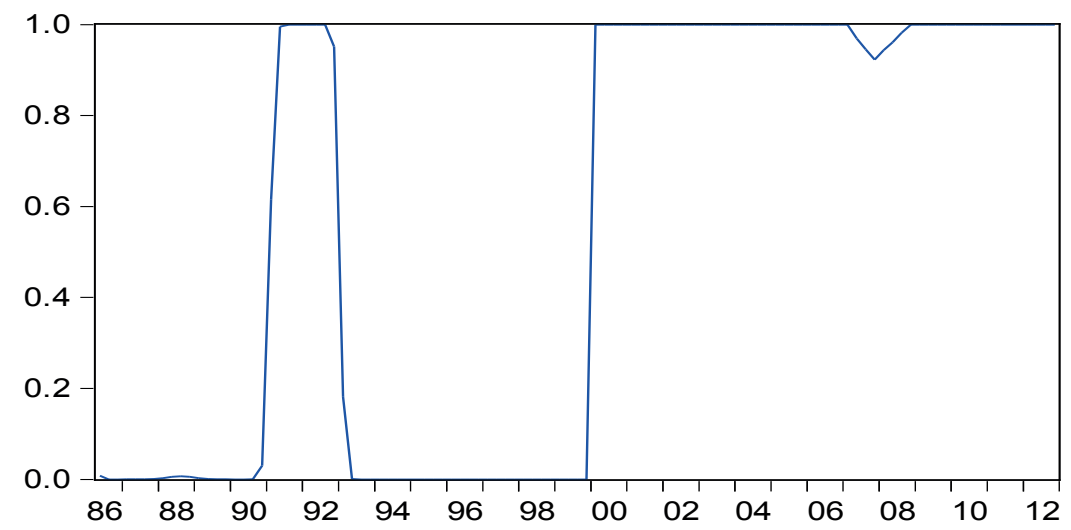

$\mathrm{b}$

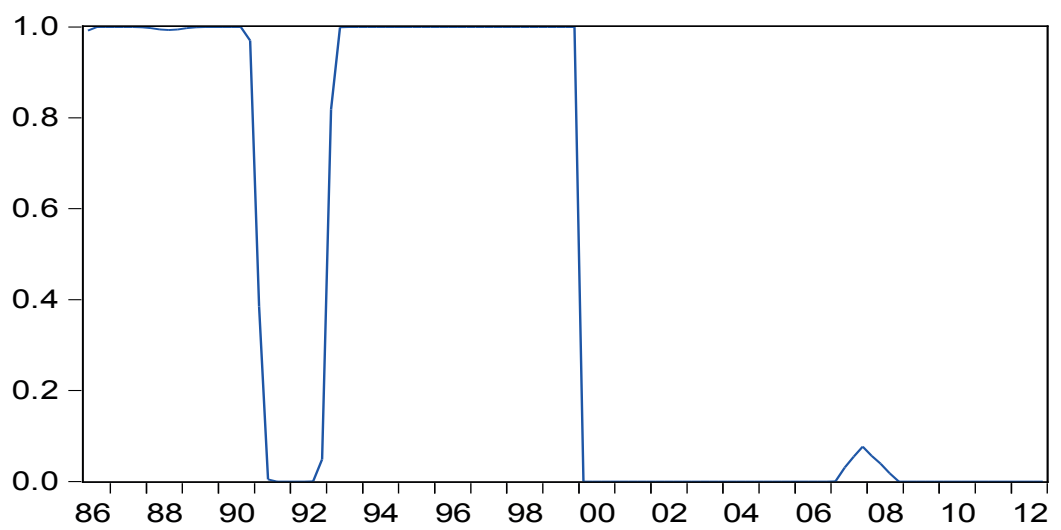

Source: Autor`s

Finally, from Figure 4a, Regime o time points are 1988:1-1992:2, 1977:3-2001:2 and 2008:1. As revealed in Figure 4b, time points for Regime 1 are 1986:1-1987:2, 1992:4-1998:4, 2001:3-2007:3 and 2008:2-2012:3. Few observations from the time points of the various regimes include one, $\mathrm{MSM}_{4}$ regime include one more time point (2008:1) into Regime o classifications in comparison with MSM1 and MSM2. This simply means that the first quarter of 2008 is not considered high. 
Figure 4.: Probability of regime o smoothed from MSM4. b: Probability of regime 1 smoothed from $\mathrm{MSM}_{4}$

a

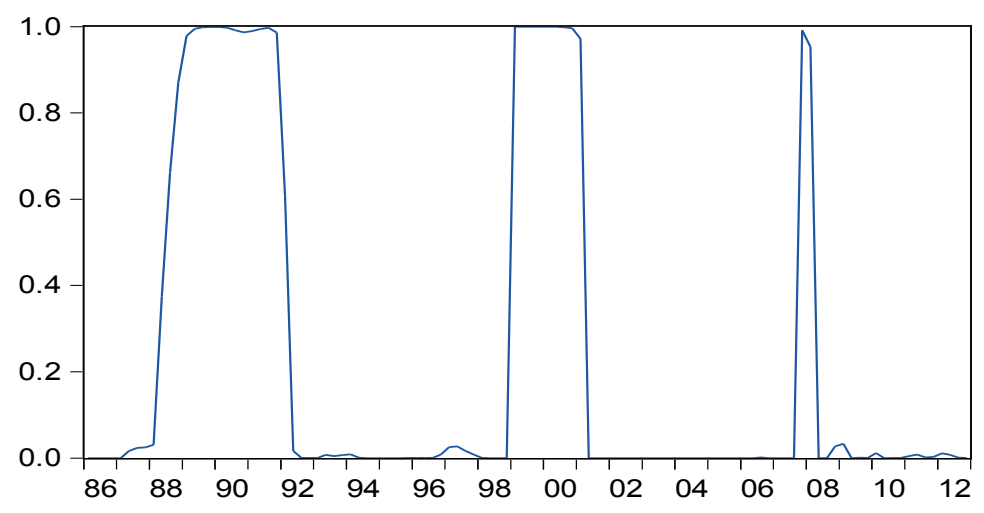

$\mathrm{b}$

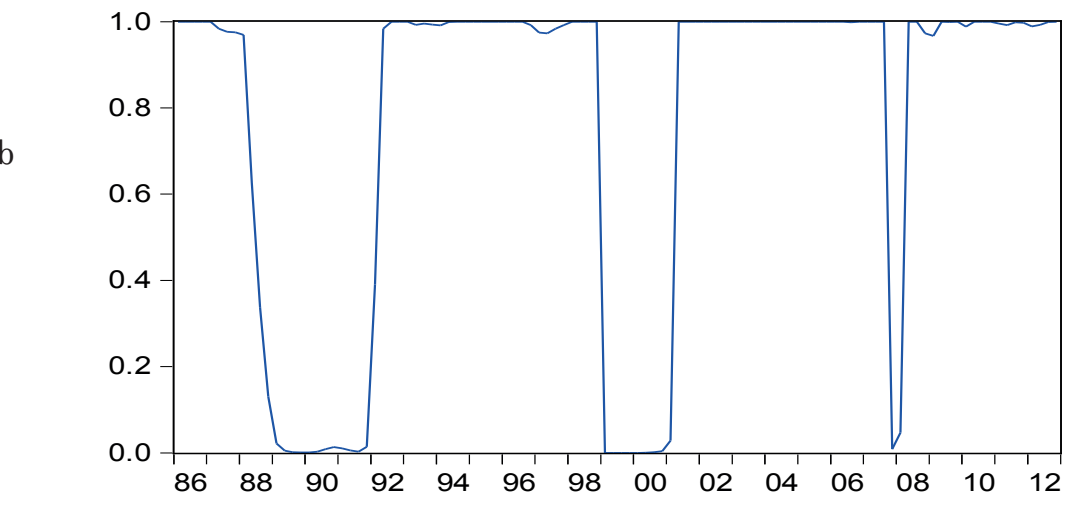

Source: Autor`s

FDI point in MSM4. Two, MSM3 adds far more time periods (2000:1-2006:4) and (2009:1-2012:3) into regime o classification in comparison with MSM1 and MSM2. Thus, by implication, means that the various quarters 2001:1-2006:4 and 2009:1-2012:3 are not considered high FDI points in MSM3. Regime o classification based on smoothed probabilities from MSMı covers 9 quarters (8.33 per centage of total) with average duration of 2 quarters. In respect of Regime 1 classification based on smoothed probabilities from MSM1, it is made up of 99 quarters (91.67 percentage of total) with average duration of 19.81 quarters. Regime o classification of MSM2 includes 35 quarters representing 32.41 percentage of the total. The percentage of Regime 1 point of $\mathrm{MSM}_{2}$, on the other hand, is 67.59. Regime o classifications of MSM3 and $\mathrm{MSM}_{4}$ include 43 and 24, quarters respectively. The percentages of Regime 1 points of MSM3 and $\mathrm{MSM}_{4}$, on the other hand, are 60.19 and 77.78 respectively. 
At this juncture, it is pertinent to understand some realizations of the Nigerian economy corresponding, in particular, to Regime o classification. Considering MSMı best among others, one may focus Regime o points of MSMr. The third quarter of 1986 pertains to the structural adjustment and liberalization programme in Nigeria (Akinlo, 1996). This programme entailed liberalization of the exchange rate, interest rate and massive export promotion. The first quarter of 1991 marked the beginning of a precipitous fall in oil price from $\$ 29.10 \mathrm{bbl}$ in 1990 to $\$ 20.50 \mathrm{bbl}$. This sharp reduction in oil price had significant adverse effect on total revenue. The trade balance ratio which was 24 per cent in 1990 dropped sharply to 0.27 per cent in 1991. The first quarter of 1998 marked the height of the banking crises which started in 1994 in the country. A total of 36 banks were liquidated in 1998 due to fraud, mismanagement, and undercapitalization. This problem led to a sharp reduction in credit flows to the private sector with adverse effects on employment, output and economic growth. Moreover, this period marked the beginning of reversion to managed floating exchange rate for the purpose of fostering competitiveness of the economy, encourage export and discourage importation. Arising from the regime shift, the naira exchange rate to dollar increased to 92.6931 as against 90.00 in the last quarter of 1999. The first to fourth quarters of 2000 represent the data points of the bitter political battle with the National assembly - in essence, to delineate the boundaries of their respective authorities under the democracy. Moreover, the new constitution, which gives state and local governments full and automatic right to their shares of the oil revenues, severely constrained the management of the oil windfall gains. Thus in 2000, oil windfall, defined as oil revenue in excess of US\$20 per Barrel (so-called excess proceeds), amounted to US \$4 billion, or 10 per cent of the GDP. Government at the both National and State levels engaged in huge spending including award of huge wages to public servant in May 2000 which precipitated increased rate of inflation and massive exchange rate depreciation. The other Regime o time points from $\mathrm{MSM}_{4}$, namely 2007:4, and MSM3 (2007:3 -2012:3) may represent global financial crises that arose from the US house bubble and the attendant increased default rates on mortgage rate. The world economy was not spared of negative spillover effect of the global financial crises. In Nigeria, several policies were initiated to mitigate the spillover effects of the global financial crises on the domestic economy. These measures included consolidation of the banking sector, reduction in the monetary policy rate and liquidity ratio (from 4,0 to 30 per cent) as well as a reduction in cash reserve requirements.

In general, from the discussion above, it could be inferred from regime classifications of MSMs that the deviations of each FDI growth rate equation from its mean are not transient. Consequently, perturbations in parameters of constant, level and some of explanatory variables would be persistent. Moreover, the findings emphasize the fact that structural changes (i.e. shocks to each FDI equation) are, in most cases, permanent. This, by implication, means that the potential or probable 
persistent shifts in parameter in time series model of FDI would generate bias and inconsistent estimators of FDI fluctuations. Hence, potential parameters shift must be taken into consideration in time series FDI modeling.

\section{CONCLUSION}

The paper examines the dynamics of FDI in Nigeria using the Markov Regime Switching approach. The study employs quarterly data for growth rates of FDI, GDP, export, import, macroeconomic uncertainty, inflation, discount rate, exchange rate, financial development and oil reserves for the period 1986:1 to 2012:4. The paper is distinct from all the previous studies in Nigeria in two ways. First, the adoption of Markov Regime-Switching models which enables us to examine FDI cycles in Nigeria taking cognizance of the potential shifts in parameters of the explanatory variables included in model including constant and trend. Second, the study runs nonlinear estimations of parameters in FDI equations after the tests for null hypothesis of linearity against alternative hypothesis of nonlinearity had been conducted.

The fundamental argument in this work is that FDI process is governed by two different states (otherwise called Regimes) and that a movement from one Regime to another is a function of the transition probabilities. Also, as found by Bilgili et al. (2012) for Turkey, a regime is determined endogenously through the inferences derived the probability of obtaining one regime (o or 1 ) depending on previous regime prevailing.

The results show that the coefficient of GDP growth rate is negative and significant in at least one regime of the four MSMs except in MSM1 (Regime 1) and MSM4 (Regime o) where it is positive. This might be that foreign investors perceive economic growth in Nigeria as non inclusive. As such, increased economic growth rate might not necessary spur foreign investment. Second, except in MSM2 and MSM3 (Regime 1 and Regime o respectively), financial development is positively correlated with FDI. Availability of natural resources (oil reserves) though positively correlated with FDI, is not a major determinant of FDI. FDI growth rate is positively correlated with exchange rate and discount rate in both Regimes but correlated negatively with inflation in regimes $\mathrm{o}$ and 1.

From policy perspectives, the following points are germane. First, government efforts at developing the financial sector will spur increase in FDI inflows into the economy. This therefore calls for more far reaching reforms in the financial subsector. The liberalization policy in the sector must be pursued to the logical conclusion as our results show that interest rate engenders increased FDI inflows. Second, there is the need to enhance the value of the domestic currency to boost higher FDI inflows. This could be done through increased domestic productivity. Third, government should ensure that the rate of inflation is maintained at low level in order not to deter FDI inflows into the country. Moreover, government efforts at reducing importation while increasing exports will serve to boost FDI inflows into the economy. 
In conclusion, preponderance evidence from the estimations shows clearly that macroeconomic factors play significant role in FDI inflows. Hence, policy makers in host country must ensure that macroeconomic policies are designed to provide enabling environment for increased FDI inflows. Also, the shifts in parameters of Markov Regime-Switching model demonstrate the need to keep track of potential possible structural changes in parameters to obtain unbiased and efficient estimations. 


\section{REFERENCES}

Abubakar, M., Abdullahi, F. A., An inquiry into the determinants of foreign direct investment in Nigeria. European Scientific Journal 9(25), (2013): 293-3०8

Ajakaiye, D. O., Foreign Direct Investment in Nigeria's Services Sector. In: Nnana, O. J., Okafor, C. M., Odoko, F. O., (eds.), Foreign direct investment in Nigeria, Proceedings of the 12th Annual Conference of the Regional Research Units of the Central Bank of Nigeria, September 1-5, (1995): 227-236

Ajakaiye, D. O., The structural adjustment programme and changes in the structure of production in Nigeria, 1986-1994. NCEMA monograph Series No. 9, 1997.

Akenbor, C. O., Tennyson O., Determinants of foreign direct investment in a democratic society: the Nigeria experience. Business and Management Review 4, (2014): 282-294

Akinlo, A. E., Adjustment programme and structural shift in the Nigerian industrial sector. Ife Journal of Economics and Finance 3(1\&2), (1996): 16-42

Akinlo, A. E., Foreign direct investment and growth in Nigeria: an empirical investigation. Journal of Policy Modeling 26, (2004): 627-639

Alfaro, R., Chanda, A., Kalemli-Ozcan., Sayek, S., Does foreign direct investment promote growth? Exploring the role of financial markets on linkages. Journal of Development Economics 91, (2010): 242-256

Al-Sadig, A., The effects of corruption on FDI inflows. Cato Journal 29(2), (2009): 267-294

Anas, J.. Billio, M. L., Duca, M. L., Business cycle analysis with multivariate markov switching models. University of Venice Department of Economics Working Papers 04 .

Ang, J. B., 2008. Determinants of foreign direct investment in Malaysia. Journal of Policy Modeling 3o, (2004): $185^{-189}$

Anyanwu, J. C., An econometric investigation of the determinants of foreign direct investment in Nigeria, Annual Conference, Nigeria Economic Society. 1998.

Anyanwu, J. C., Determinants of foreign direct investment inflows to Africa, 1980-2007. African Development Bank Group, Working Paper No. 136, September 2011.

Anyanwu, J. C., Erhijakpor, A. E. O., Trends and determinants of foreign direct investment in Africa. West African Journal of Monetary and Economic Integration, second Half, (2004): 21-44

Aremu, J.A., Foreign private investment: issues, determinants and performance. Paper presented at a workshop on foreign investment policy and practice, Nigerian Institute of Advanced Legal Studies, Lagos, 1997 .

Asiedu, E., On the Determinants of foreign direct investment to developing countries: is Africa different? World Development 3०(1), (2002): 107-119

Asiedu, E., Foreign direct investment in Africa: the role of natural resources, market size, government policy, institutions and political instability. World Economy 29, (2006): 63-77

Azrak, P., Wynne, K., Protectionism and Japanese direct investment in the United States. Journal of Policy Modeling 17, (1995): 293-305

Bilgili, F., Tülüce, N. S. H., Doğan, I., The determinants of FDI in Turkey: a Markov regime-switching approach. Economic Modelling 29, (2012): 1161-1169

Boateng, A., Hua, X., Uddin, M., Du, M., Home country macroeconomic factors on outward cross-border mergers and acquisitions: evidence from the UK. Review of International Business and Finance 3o,

(2014): 202-216 
Boating, A., Hua, X., Nisar, S., Wu, J., Examining the determinants of inward FDI: evidence from Norway. Economic Modelling 47, (2015): 118-127

Buckley, J. P., Clegg, L. J., Cross, A. R., Xin, L., Ping, Z., The determinants of Chinese outward foreign direct investment. Journal of International Business Studies 38, 499-518.

Campa, J. M., 1993. Entry by foreign firms in the United States under exchange rate uncertainty. Review of Economic Statistics 75, (2007): 614-622

Chauvet, M., An econometric characterization of business cycle dynamics with factor structure and regime switching. International Economic Review 39(4), (1998): 969-996

Chette, L. C., Determinants of FDI: an error correction specification. Nigerian Journal of Economic and Social Studies 4, (1), (1998): 1-17

de Mello Jr, L. R., Foreign direct investment-led growth: evidence from time series and panel data. Oxford Economic Papers 51, (1999): 133-151

Deihmann, J., Karidis, S., Sayek, S., Foreign direct investment in Turkey: regional determinants. Applied Economics 35, (2003): $1767^{-1} 77^{8}$

Dunning, J. H., Trade location of economic activity and the MNE: a search for an eclectic approach. In: Ohlin, B., Hesselborn, P. O. (Eds.), The International Allocation of Economic Activity, Macmillan, London, (1977): 395-418

Dunning, J. H., Explaining the international direct investment position of countries toward a dynamic or development approach. Weltwirtschaftliches Archiv 117, (1981): 3o-64

Dunning, J. H., The eclectic paradigm of international production: a restatement and some possible extension. Journal of International Business Studies 19(1), (1988): 1-31

Dunning, J. H., Multinational Enterprises and the Global Economy. Addison-Wesley, Workingham, 1993

Dunning, J, H., Location and the multinational enterprise: a neglected factor?". Journal of International Business Studies 40, (2009): 5-19

Durland, J. M., McCurdy, T. H., Duration dependent transitions in a Markov model of US GNP growth. Journal of Economic and Business Statistics 12, (1994): 279-288

Edwards, S., Capital flows, foreign direct investment, and dept-equity swaps in developing countries. National Bureau of Economic Research (Cambridge, M.A) Working Paper No. 34.97, 1990

Ekperware, C. M., Oil and nonoil FDI and economic growth in Nigeria. Journal of Emerging Trends in Economics and Management Sciences 2, (2011): 333-343

Ekpo, A. H., 1997. Determinants of foreign direct investment in Nigeria: evidence from time series data. CBN Economic and Financial Review 35(1), (2011): 59-78

Feils, D.J., Rahman, M., Regional economic integration and determinants of foreign direct investment: The case of NAFTA, Management International Review 48(2), (2008): 147-163

Frommel, M., MacDonald, R., Menkhoff, L., Markovswitching regimes in a monetary exchange rate model. Economic Modelling 22, (2005): 4.85-502

Froot, K., Stein, J. C., Exchange rates and foreign direct investment: an imperfect capital markets approach. Ouaterly Journal of Economics 106, (1991): 1191-1217 
Ghysels, E., On the Economics and Econometrics of Seasonality. Invited paper, 1990 World Congress of the Econometric Society, August 1990. In: Sims, C. A. (Ed.), Advances in Econometrics 1. Cambridge University Press, (1994): 257-316

Hawawini, G. V., Schill, M., The Japanese presence in the European financial sector: historical perspective and future prospects. In: Maso, M., Encarnation, D. (Eds.). Does Owner ship Matter: Japanese Multinationals in Europe. Oxford University Press. Oxford, 1994.

Hamilton, J. D., Rational-expectations econometric analysis of changes in regime: an investigation of the term structure of interest rate. Journal of Economic Dynamics and Control 12, (1988): 385-4,23

Hamilton, J.D., A new approach to the economic analysis of non-stationary time series and the business cycle. Econometrica 57 (2), (1989): $357^{-384}$

Hamilton, J. D. Analysis of time series subject to changes in regimes. Journal of Econometrics 45, (1990): $39^{-} 70$

Hausmann, R., Fernandez-Arias, E., The new wave of capital inflows: Sea change or just another title? Inter-American Development Bank Working Paper No. 417, 2000.

Jaspersen, F., Aylward, A.H., Knox, A.D., The Effect of Risks on Private Investment: Africa compare with other Developing Countries. In Collier, P., Pattillo, C., (Eds.), Investment and risk in Africa. St Martin's Press, New York, (2000): 71-95

Jeanne, O., Masson, P., Currency crises, sunspots and Markov-Switching Regimes. Journal of International Economics 50, (2000): $327-350$

Joen, B. N., Rhee, S. S., The determinants of Korea's foreign direct investment from the United States, 1980-2001: an empirical investigation of firm level data. Contemporary Economic Policy 26, (2008): $118-131$

Khair-UZ-Zaman, H. S., Awan, Z, Economic determinant of foreign direct investment in Pakistan, Gomal University Journal of Research 22, (2006): 49-57

Khan, R, E. A., Nowaz, R. E. A., Economic determinants of foreign direct investment in Pakistan. Journal of Economics 1, (2010): 99-104

Kim, H., Political stability and foreign direct investment. International Journal of Economics and Finance 2(3), (2010): 59-71

Kim, C. J., Nelson, C. R., State-space Models with Regime Switching. MIT Press, Cambridge, Massachusetts London, England, 2000

Kiymaz, H., The impact of country risk rating on US firms in large cross-border acquisitions. Global Financial Journal 20, (2009): 235-247

Krolzig, H. M., Predicting Markov-switching vector autoregressive process. Nuffield College Economic Working Papers W31, 2000.

Krolzig, H. M., Markov-switching procedures for dating the Euro Zone business cycle. Vierteljarshefte zur Wirtschaftsforschung 70 (3), (2001): 339-351

Kuan, C. M., Lecture on the Markov Switching. Institute of Economics Academia Sinica. 2002. http: idv. sinica.edu.tw/ckuan/pdf/lecmarkn.pdf, last accessed on January $5,2015$.

Kuan, C. M., Lecture on Markov Switching. Department of Finance \& CRETA, National Taiwan University. 2010. http://homepage.ntu.edu.tw/-ckuan/pdfLec-Markov_slide_Spring2010.pdf, last accessed on January 5,2015 . 
Kwiatkowski, D., Phillips, P. C., Schmidt, P., Shin, Y. Testing the null hypothesis of stationary against the alternative of a unit root. Journal of Econometrics 54, (1992): 159-178

Lam, P., A Markov switching model of GNP growth with duration dependence. International Economic Review 45(11), (2004): 175-204

Lawrence, C., Tits, A., A computational efficient feasible sequential quadratic programming algorithm. SIAM Journal on Optimisation 11, (2001): 175-204

Lee, S. H., Levendis, J., Guitierrez, L., Telecommunication and economic growth: empirical analysis of sub-Saharan Africa. Applied Economics 44, (2012): 461-469

$\mathrm{Li}, \mathrm{X}$., Liu, X., Foreign direct investment and economic growth: an increasingly endogenous relationship. World Development 33, (2005):393-4.07

Liu, P., Mumtaz, H., Evolving macroeconomic dynamics in a small open economy: an estimated markovswitching DSGE model for the United Kingdom. Bank of England, Working Paper No. 397, 2010

Liu, X. M., Shu, C., Sinclair, P., Trade, foreign direct investment and economic growth in Asian economies. Applied Economics 41, (2009): 1603-1612

McCulloch, R., Japanese investment in the United States. In: Audretsch, David B., Michael, P. Claudon

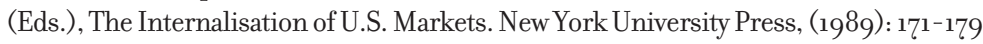

Mohamed, S. F., Sidiropoulos, M. G., Another look at the determinants of foreign direct investment in MENA countries: an empirical investigation. Journal of Economic Development 35, (2010): 75-95

Nnadozie, E., Osili, U. O., Foreign direct investment in Africa and its determinants. UNECA Workshop of Financial Systems and Mobilisation in Africa, Nov $2{ }^{\text {nd }}{ }_{2004}$.

Obadan, M.I., Direct investment in Nigeria: An empirical analysis. African Studies Review 25, (1982): $67^{-81}$

Oladipo, O. S., Foreign direct investment flow: determinants and growth effects in a small open economy, Proceedings of the Northeast Business \& Economics Association, Northeast Business \& Economics Association 35th Annual Conference, Long Island, New York, November 6th - 8th, 2008.

Omonkhanlem, A. E., Foreign direct investment and its effect on the Nigerian economy. Business Intelligence Journal 4, (2011): 253-261

Oyatoye, E. O., Arogundade, K. K., Adebisi, S. O., Oluwakayode, E. F., Foreign direct investment, export and economic growth in Nigeria. European Journal of Economic and Social Studies 2, (2011): 67-86

Oyinlola, O. External capital and economic development in Nigeria (1970-1991). Nigerian Journal of Economic and Social Studies, 37, (1995): 205-222

Ramirez, M. D., Economic and institutional determinants of foreign direct investment in Chile: A timeseries analysis, 1960-2001. Contemporary economic policy, 24: 459-471.

Raymond, J. E., Rich, R. W., 1997. Oil and the macroeconomy: a Markov-Switching approach. Journal of Money, Credit, and Banking 29(2), (2006): 193-213

Ribeiro, P. F., Pereira, P. V., Economic cycles and term structure application to Brazil. Escola De Economia De Sao Paulo Da Fundacao Getulio Vargas FGV-EESP, 2010. http://econspapers.repec,org/ PePEc:fgv:eesptd:259, last accessed on April 23, 2014.

Simon, J., A markov-switching model of inflation in Australia. Economic Group Reserve Bank of Australia, Research Discussion Paper 9611, 1996. 
Smith, P. A., Summers, P. M., How well do Markov switching models describe actual business cycles? The case of synchronization. Journal of Applied Econometrics 20(2), (2005): 253-274

Thaddeus, E. O., Yadirichukwu, E., Determinants of foreign direct investment inflow: a focus on Nigeria. European Journal of Business and Management $5,(2013): 41^{-5} 5^{2}$

Wafure, O. G., Nurudeen, A. Determinants of foreign direct investment in Nigeria: an empirical analysis. Global Journal of Human Social Science 10(1), (2010): 26-34

Walsh, J. P., Yu J., Determinants of foreign direct investment: A sectoral and institutional approach, IMF Working Paper WP/10/187, 2010.

Vasconcellos, G. M., Kish, R. J., Cross-border mergers and acquisitions: the European-US experience. Journal of Multinational Financial Management 8(4), (1998): 431-450

Yang, J. Y. Y., Groeneworld, N., Tcha, M., The determinants of foreign direct investments in Australia. Economic Records 76, (2000): 45-54

Yao, S., On economic growth, FDI and exports in China. Applied Economics 38, (2006): 339-351 